\title{
Internalizing Economic Externalities on the Macroeconomic Stage. Exploring and Expanding Paul Hawken's The Ecology of Commerce: A Declaration of Sustainability for Globalized Solutions
}

\author{
Jay Cooper Beeks ${ }^{1,2 *}$, Alexander Ziko ${ }^{3}$
}

${ }^{1}$ Marylhurst University, Marylhurst, OR, USA

2 Arizona State University, Tempe, AZ, USA

${ }^{3}$ Franklin Pierce University, Rindge, NH, USA

\section{*Corresponding Author: jaycbeeks@gmail.com}

Citation: Beeks, J. C. and Ziko, A. (2018). Internalizing Economic Externalities on the Macroeconomic Stage. Exploring and Expanding Paul Hawken's The Ecology of Commerce: A Declaration of Sustainability for Globalized Solutions. European Journal of Sustainable Development Research, 2(1), 03. https://doi.org/10.20897/ejosdr/76752

Published: January 30, 2018

\begin{abstract}
The problem of finding the method and means of internalizing the costs of externalities has stumped economists since Arthur Pigou first presented this issue in 1920. Since Pigou, several mainstream economists and alternative economists have attempted to further his ideas because of the promise of curbing consumer behaviors and thereby reducing detrimental activities such as the production of greenhouse gases. The current call for a carbon tax to stem the causes of Global Climate Change is just one example of a present day method of internalizing externalities. Of all of the modern day proponents for a carbon tax and other forms of "green fees", however, Paul Hawken is arguably the most ardent supporter, believing this to be the most effective method of stemming many of humankind's pollution activities. His best selling book The Ecology of Commerce, A Declaration of Sustainability is examined here further, in order to explore Hawken's arguments for these kinds of microeconomic solutions and to expand on these ideas to include macroeconomic solutions as well. As Hawken and others have noted, global climate change presents a size issue that must be countered using global forces in addition to microeconomic solutions such as with green fees. This paper explores how global problems such as global climate change can be countered with the aid of international organizations for the benefit of global citizens.
\end{abstract}

Keywords: internalizing externalities, green fees, carbon tax, macroeconomic, Paul Hawken, GHG, GCC, global citizens, World Trade Organization

\section{INTRODUCTION}

Limits act as signals to either encourage us to act in one way or to discourage us from acting in another way. There are limits to everyday life that society places on us, or that society places upon itself. Speed limits tell us not to drive too fast, a myriad of signs such as no smoking signs restrict our behaviors, and the price of things helps consumers to gauge how much they can afford to spend on something. Just like there are limits to human designed systems, there are also natural limits that have evolved over countless millennia throughout the world's ecological systems. Through natural actions and natural selection processes, species flourish, collapse, and adapt as they act in their own self-interests while responding to these signs or signals. The critical difference between the natural world and the human designed world is self-evident within their titles - the natural world is natural and the human designed world is artificial (Wells, 2013). What this diametrical comparison suggests is that what is created in the 
natural world can be absorbed by nature in a sustainable amount of time, and what is created in the humandesigned world has the ability to remain for an unsustainable amount of time.

The objective of this paper is to explore the unsustainability of certain human actions, examine the solutions to these actions as presented in Paul Hawken's The Ecology of Commerce: A Declaration of Sustainability, and to expand this discussion to include global macroeconomic solutions in addition to Hawken's (2010) microeconomic solutions. The approach to this research is theoretical, using the hypothesized perspectives and findings of others. This research evidence, in turn, is weighed and interpretations are made that lead to solutions and answers. The information is collected from a variety of sources, interpreted and then presented here (Bentz and Shapiro, 1998).

This research is also rooted in transdisciplinarity, a research methodology that is well suited to realizing the connectedness and intricacy of different disciplines (Montuori, 2010; Wells, 2013). This transdisciplinary investigation examines the paradigmatic assumptions that are a part of disciplinary discourses, investigates how these assumptions bias and limit understanding within those dialogues, and explores the inferences of the alternative paradigms (Montuori, 2008). The findings of this research are limited to the findings of others and the accuracy of the findings of others. In addition, this research uses Paul Hawken's (2010) findings as a basis for the examination of global macroeconomic solutions. The findings of Hawken's theoretical research, therefore, provides an additional limitation on the efficacy of the solutions presented here.

\section{THE DUALITY OF HUMAN AND NATURAL SYSTEMS}

This dual existence of action and reaction in the efforts of both self-indulgence and survival are mirrored in the world of industry and in the world of ecology. Trees drop many seeds in an attempt replicate themselves; as a result of this action, foraging animals collect the excess as food for themselves to support their survival. These same trees collect water, converting it to oxygen whilst converting carbon dioxide into carbohydrates, all part of the photosynthesis process. Mammals and other animals breath in the oxygen, converting around 5\% of that inhaled back to carbon dioxide for the benefit of plants, all part of a give and take balanced cycle. Plants support animals and animals support plants with some extra allowances from one to the other, sometimes referred to as an externality. In one case, this externality is an effectual byproduct of the trees action, and because it helps support other animals it is a positive externality.

In a postindustrial western economy, industry also acts within its own self-interest in order to survive and reap the benefits of certain resources. Neoclassical economics promotes this action - to match supply with demand and to benefit as much as possible from the use of resources. Like trees that produce oxygen and seeds, industrial factories produce externalities as well. Negative externalities like greenhouse gas (GHG) emissions and water pollution are effects of the factory responding to incentives and responding as a rational actor. These negative externalities, however, such as atmospheric pollution with higher levels of GHGs, lead to global climate change (GCC), negatively impacting both human and natural systems. Thus, an imbalance occurs in the interactions between natural systems such as forest systems and human systems such as industry. Human systems utilize natural resources such as oxygen, water and fossil fuels, and in the process, produce excess gases such as carbon dioxide along with other GHGs in addition to other forms of pollution to air, water and land systems. These excess gases and other forms of pollution are identified here and elsewhere as negative externalities.

Industrial negative externalities are dangerous for a number of reasons. They draw down on the natural capital of ecosystems, for instance and they threaten human systems as well. Extracted critical resources such as fresh water, lumber, minerals, fossil fuels, rock and soils diminish natural ecological systems resulting in a kind of taking negative externality. Negative externalities imposed upon the environment are onerous not only because of the resulting damage to these environments but also because they belie the true cost of production. Therefore, these natural systems are diminished and the cost of this damage is not accounted for in the cost of many goods and services. Arthur Pigou first identified this lack of accounting for the true cost of a good or service into the marketable cost as a "market failure" with his book The Economics of Welfare published in 1920 (Pigou, 2013). This apparent lack of accounting and lack of accountability is a transferred cost on both society and onto natural systems, with natural systems incurring the brunt of the cost. These, in effect, cost savings for the enterprises that are selling goods or services at below accurate and reasonable market prices, in turn, when multiplied many thousands of time, create globally dangerous conditions for all concerned.

A simplistic example of a negative externality is summed up in Victorian economist William Foster Lloyd's "the tragedy of the commons" concerning the paradox that is created when consumers (farmers) of a shared resource (a town common) act against all of the farmer's best interest (Hardin, 2009). In this unregulated shared green space, cattle are allowed to graze freely, however, some farmers acting in their own self-interest allow their cattle to overgraze, thereby negatively impacting the other farmers who wish to use this common land. This overgrazing depletes the collective and common good through unsustainable means. Without regulation to prevent this overgrazing, the common is overexploited, rendering the land unusable for anyone. Much the same occurs when 
a human system such as a given industry either depletes a natural resource excessively or pollutes a natural resource excessively. And since human systems depend on the health and vitality of natural systems, one industry or individual's action resulting in the depletion or pollution of natural systems then negatively impacts other human systems.

Many economists and ecologists have discussed the depletion of natural resources (natural capital) and how this depletion is related to contemporary commerce. Pigou "argued that a market failed if producers did not bear the full cost of production, including whatever pollution, sickness, or environmental damage they cause" (Hawken, 2010, p. 92). Pigou's optimistic contention was that once the producer internalized the true cost of a product, then the producer would react through innovation to reduce their cost, like any other rational actor operating in the market would. The focus on these Pigovian taxes would be on two major costs. The first would be on the actual accounting cost of the damages caused by producers, the second would be on the cost to future generations (Hawken, 2010). Paul Hawken, has written in depth on the subject of environmental economics in works such as Natural Capitalism: Creating the Next Industrial Revolution and The Ecology of Commerce: A Declaration of Sustainability. His position is on the side of commerce, arguing that for one to truly experience the genius of enterprises, then it is necessary to include externality costs into the price of goods and services and then let these enterprises respond with the kind of innovative solutions needed to minimize these additional costs in the manner industry has proven itself highly capable of. His goal is not to punish some, but rather to provide positive incentives for innovation and to more accurately reflect the cost of goods and services.

In his book The Ecology of Commerce, however, Hawken expands on the notion that business has become sidetracked with the idea that making money should be the only identifier of success. His concern, shared by many alternative economists today, is that industries acting under a dearth of existing capitalism limits, are encouraged to place too much emphasis on profit and as a result, harm both human and natural systems with the creation of uncontrolled and unaccounted for negative externalities. He forwards the idea that money alone does not make you wealthy and that businesses true calling to the world to "increase the wellbeing of humankind through service, creative innovation, and creative invention" (Hawken, 2010. p. 2). Profit, he argues, should be a beneficial byproduct of capitalistic enterprises that are focused on benefiting society first. Critically, Hawken (2010) contends that "any time there is inefficiency in the form of pollution or waste - it is uneconomic and therefore more costly" (p. 152).

Hawken is supported by others such as Naomi Klein (2014) with This Changes Everything: Capitalism Versus the Climate and Bill McKibben's (2011) eaarth, both pointing to the problems with certain capitalism practices as the cause of the greatest threat of our time, GCC. They along with the majority of the scientific community see the global threat of climate change, as the game changer, a result of human actions that is going to force our societies to respond to long term needs, long term threats, and to recognize that the seemingly intangible consequences of GHG production are just as real as are the consequences of war. These researchers also realize that threats such as this are highly complex, interconnected with most human activities and are going to require more than just a few disciplines to solve it. Combating a threat such as GCC requires the aid of environmental scientists, economists open to the need for adjustments to capitalism, and a host of other disciplines all working together to eventually control and reduce human caused negative externalities such as GHG production.

Climate change is in fact, a multidimensional and multidisciplinary problem that is affecting more than just the natural world (Wells, 2013). Solving this problem, therefore, will require not only a multidisciplinary response but also a paradigm shift in thinking. This need becomes clear when the basic principles of economics are applied to the study of making choices based on limited resources, while the resources that need to be managed are the natural capital and the systems of ecology that natural capital can be found in. Complicating matters, economists must take into account downstream systems such as climate, environmental impact and public policy.

Hawken (2010) reinforces this need for a multidisciplinary response and new thinking by reminding us that the hypothetical burning of all fossil fuels (reserves of coal, oil and gas) would increase Earth's atmospheric concentration of $\mathrm{CO}_{2}$ ten fold - resulting in further amplified runaway greenhouse conditions on Earth, soon rendering our planet as liken to Venus. Naturally, the idea of turning Earth into Venus is not a popular one, in fact, our goal must be to keep existing levels of CO2 at or below 400 parts per million (Hawken, 2010). However, the challenge of stopping the carbon burning process exemplifies the need for new thinking, acceptance of the intangibility of the problem as well as the abandonment of anthropocentric ideologies that act as a deterrent to a rational and a reasoned response to the problem. As Hawken points out, our societies need long-term thinking that will result in long-term carbon management with the aid of knowledgeable climatologists, environmental scientists, industry experts, and economists. Clearly, as Hawken and many others contend, solving the problems of GCC is a complex and time consuming task, however, it is vital to ensure the survival of all those who depend on the natural world's health. Thus, it is an essential task, not deserving of irrational responses or ideologically inspired debate and rather, one that requires our unwavering as well as unending devotion. 


\section{GREEN FEES, TAXES, AND UTILITIES}

The concept of adding green fees or taxes to the price of goods again goes back to the proposals of Pigou, with an example today coming in the form of a carbon tax, as advocated for by Hawken and economists such as Paul Krugman (2010), designed to specifically target goods and services which produce carbon pollution. Decidedly, the taxing of energy production with methods such as carbon taxing, promises to be highly beneficial in the short term and will lead to widespread innovation in the long term (Hawken, 2010). To understand the importance of green fees and taxes (sometimes referred to as sin taxes) it is important to understand that the free market system is not really free. Which is to say, that the true cost of goods and services are only rarely represented in their transaction of sale cost. Paraphrasing the well-known writer and philosopher G. K. Chesterton and quoting Hawken (2010), "there is nothing wrong with a free market; it's just that no one has tried it yet" (p.145). Currently, the cost of goods and services does not include the cost for the externalities generated by the production of the goods and services purchased. When prices are attached to goods, for example, the costs of labor, raw materials, and operations and maintenance are typically accounted for; however the dollar amount of pollution produced, human rights violations, or harm caused to future generations are not taken into account when the product or service is sold. Since these external costs are not accounted for, then the true price of the product or service is not being paid at the point of transaction. A free market, it is argued would include equal allowance for externalities from one producer to another, thereby leveling the playing field and providing fair competition from one company to the next. Furthermore, this market failure allows for negative externalities to happen because the producer is under no incentive to modify their business model (Pigou, 2013).

In these cases, the producer acts as a rational actor (just as the farmer in the tragedy of the commons), acting in their own self-interest but not in the collective good of the larger community. The fallacy of free trade today is that one country selling goods under the auspices of strict environmental regulations along with other production limitations cannot compete fairly or freely with another country that does not require or enforce these same restrictions. Green fees and taxes are proposed then to counter the existing conditions of unfair trade and to minimize the production of negative externalities. These green fees and taxes work both as disincentives and as incentives to producers. Similar taxes today include taxes on cigarettes and on gasoline. Green fees inhibit producers from cutting corners with regard to greenhouse gas emissions and other forms of pollution, and at the same time, they promote innovation into areas such as energy efficiency with these savings incorporated into the total cost analysis of the business practices. It needs to be noted as well that these kinds of green fees and taxes are highly inexact, and yet they still influence consumer behavior as well as the manufacturing and distribution practices of the producers ( $\mathrm{Li}, \mathrm{Lin}$ and Muehlegger, 2014).

\section{Regulatory Policy}

There are two primary policy responses needed to control externalities such as pollution, regulatory and marketbased policies (Hill and Clifford, 2015). Regulatory policies are rules that are created by government bureaucracies that restrict elements used in production. An example would be the 2007 ban of trans fats in New York City restaurants. In this case, City restaurants were disincentivized to use a substance that was directly related to the negative externality of heart disease in a densely populated city. Regulatory policy is a clear-cut and a simple way to address market failures found in an economy. However, a limitation to regulatory policy is that it often does little to generate revenue for the regulatory body, and does not tend to promote positive externalities. Importantly, too much regulatory policy can quickly get out of hand, sending confusing signals to producers and in doing so, stifle innovativeness as well as production (Hawken, 2010). Nonetheless, regulatory policies and regulations, if done properly, without needless complexity, provide essential guidelines and benchmarks on local, national and international scales.

\section{Market based policy}

A market-based policy is designed to manipulate markets into generating value, through innovation in specific areas of the economy, while disincentivizing negative externalities at the same time. Furthermore, a market-based policy can provide essential funding for regulatory agencies because it can create needed revenue for the agency. The most common types of market-based policy are taxes and subsidies. Taxes imposed on products (like gasoline) will drive up the cost to consumers, encouraging them to change their consumption habits - walk or bike more, carpool, etc ( $\mathrm{Li}$, Lin and Muehlegger, 2014). Taxes collected are earned revenue that can be used to support the community as well as supporting other needs such as for critical new technology. This revenue support can be used designing transportation systems that are friendlier toward bikers and walkers, or can be used to fund a public transportation system.

Subsidies, on the other hand, are capital allocations toward investments, or projects with a specific purpose (Hill and Clifford, 2015). Examples of subsidies are rebate offers for solar panels, renewable energy credits toward 
renewable power producers, or grants toward more efficient technologies. Both taxes and subsidies, however, interact with the economy in ways that are dynamic and that can be used for the benefit of the community. Other common taxes, by comparison, such as income or payroll tax, do not produce significantly tangible benefits. Essentially, payroll and income taxes do not generate the kind of reciprocity desired by either their creators or for those who pay into them. Furthermore, some taxes encourage citizens to find tax loopholes and tax havens to prevent paying into the tax base altogether.

With a restructuring of tax policy, conversely, and a reallocation of tax revenue, it is possible to redirect the taxes generated to create a more efficient and reciprocal use by promoting energy innovation, efficiency, and consumption behavior thereby creating more positive feedback rather than continuing with a system of taxes that encourage more deceitful accounting practices (Hawken, 2010). Furthermore, green fees and taxes themselves are likely to increase as sustainability practices become mainstream with policy makers eventually seeing the advantages of this kind of revenue generation. Even so, an important thing to consider with the implementation of green taxes to represent the true cost of goods is to understand that the taxes should be implemented gradually. To avoid shocking the system with high taxes, these taxes need to be small initially and to gradually increase over the course of 10 to 20 years (Hawken, 2010). Like emission standards on new cars or on new factories, these taxes will need to gradually push the tax base away from the current status quo and toward one that is designed with the collective good in mind.

\section{Utilities}

The proliferation of utility enterprises is another way to fund sustainable actions and to promote green initiatives. Utilities are an established method of allocation and use of critical resources and have come to represent one of the more promising solutions to the tragedy of the commons (Hawken, 2010). Utilities are a unique fixture in our free market system, because of their structure. They are held accountable to public utility commissions and regulatory practices, but they also provide a near monopoly on their respective markets. This gives them a guaranteed and steady revenue stream, as well as an ability to acquire low interest rates for needed capital based on the safety of their bonds (Hawken, 2010). Customers also benefit from the presence of utilities. For instance, customers gain from subsidies provided to reduce their energy consumption, which in-turn prevents utility companies from having to raise capital for new power plants (to meet high demand). The reason this works so well is because the cost of retrofitting a home with energy star appliances, for instance, and new insulation is less than one tenth the cost the consumer would pay in new utility rates if a new generation plant was to be built (Hawken, 2010). This give and take relationship between the company and the customer allows for a unique method of conservation, allowing a marginal profit for a utility by essentially "selling the absence of something" all the while giving the customer a break on the cost (Hawken, 2010, p. 165).

\section{How is Increased Efficiency and Renewable Energy Cost Effective in the Aggregate}

One of the most common arguments against the incorporation of increased technologies to increase energy efficiency or transfer to a totally renewable source of energy is that the capital startup cost would be too great (Panwar, Kaushik and Kothari, 2011). And yet, renewable energy such as wind power is currently being produced at prices at or below the price of electricity from natural gas generating stations. Short term thinking toward long term solutions often results in faulty thinking. Believing that improving the operational efficiency of a supply chain, for instance, or that investing in a new source of renewable energy would not result in realistic payback periods, are examples of linear, and often faulty short-term thinking. The reality is that society is already paying hidden costs associated with the negative externalities associated with countless industrial and manufacturing processes. Medical care paying for respiratory diseases, for instance, higher cancer rates from contaminated air and water pollution, the increased frequency of super storms and rising sea levels are all resulting in a financial burden on society. There are circular loop, systems consequences to faulty short-term thinking and short-term solutions based on limited information with erroneous assumptions lead to flawed decisions.

These seemingly extraneous consequences of pollution, for example, create financial burdens that are out of the hands and out of the control of the original perpetrators with the financial costs of this pollution essentially hidden in obscurity (Pigou, 2013). This kind of short term thinking may be compared to townspeople not wanting to increase a budget for road work claiming that they don't want to pay more in taxes - however the deteriorating conditions of the road lead to an out of pocket cost associated with: new car struts, flat tires, and ball joints; and in the end the repairs to the road systems cost more because the problems increase with time. All too often, due to the lack of spending on long-term investments such as on infrastructure needs, for instance, simply leads to higher costs that are eventually absorbed by society with the hardest hit being those in lower income brackets who can neither afford adequate health care, or expensive car maintenance.

Ray Anderson, the highly successful founder of Interface, Inc., provided us all with concrete examples of how a major corporation can both make sustainable improvements toward their value chain, while also maintaining a 
healthy revenue stream. These goals take both time, strategic design, and a healthy corporate culture. As Ray Anderson stated: "I always make the business case for sustainability. It's so compelling. Our costs are down, not up. Our products are the best they have ever been. Our people are motivated by a shared higher purpose - esprit de corps to die for. And the goodwill in the marketplace - it's just been astonishing" (Anderson, 2007, para. 30). Anderson took one of the world's largest and most successful carpet and tile companies, and put them on a track to an even more successful company with a goal of zero environmental impact by the year 2020 .

Just as Interface was able to find ways to save on costs by being more sustainable, many other companies have shown how they can make innovative changes in response to the high costs of production, such as with higher energy costs. Importantly, just 100 companies are responsible for over $70 \%$ of global emissions and therefore with the help of these companies alone, we can make great strides at reducing GCC inputs (The Guardian, 2017). While citing a study of economies and resource consumption from 1976 to 1990, for instance, Hawken (2010) explains the long term environmental benefits of higher energy costs by emphasizing that industry will adapt to changes in the market leading to innovations, which in turn will create a demand for such innovations and will eventually lower their costs. Even today, the global investments in renewable technologies are up six fold as compared to just ten years ago (The Economic Times, 2017). Industry, Hawken (2010) enlightens, is fantastic at finding innovative solutions to many things, including avoiding higher costs, often resulting in more efficient operations and better more sustainable products.

A study of the economies of Japan, the United States, the erstwhile USSR, and the European Union... showed that economic performance was directly correlated with energy prices. The more costly the prices of resources, as in the case of Japan, the greater the technological innovations and economic growth. On the other hand, where energy and resources were subsidized and below market value, as they were in the Soviet Union, economic growth and innovation lagged significantly behind. The United States outperformed the USSR but did not best the EU, which has taxed energy to significantly higher levels than the United States but not as high as Japan" (p. 154 - 155).

A more contemporary example of the benefits of increasing the price of energy can be found in Germany with the feed-in-tariff system (Mabee, Mannion and Carpenter, 2012). Germany is arguably the world leader in renewable energy with over $40 \mathrm{GW}$ of rooftop solar at the end of 2015, thanks to the innovation sparked by the feed-in-tarriffs and accelerated by higher energy prices.

When one looks at the cost of energy while managing the productive output of a system, one would think that any sort of shift in how energy is used would cause a massive upheaval in the way that products are produced. However, again this is a fallacy. Market systems are debatably blind to many of the primacies of societies, and will remain so unless they are required to accept and adapt to societal priorities. Before the industrial revolution the bulk of energy used to produce goods was through slavery; and yet there is no longer an open market for sale of human beings for this purpose or any other (Hawken, 2010). Governments, with the encouragement of citizen actions, regulated that source of energy and the industrial entity of commerce adapted, giving way to innovation with more mechanized forms of production. As Hawken (2010) reminds us, "Market prices reflect the present and only the present. Social justice and the environment represent the future, and integrating them requires regulation" (p. 92).

\section{MACROECONOMIC SOLUTIONS}

Considering that commodity, goods and services price adjustments are the microeconomic method of internalizing externalities, then it behooves us to consider macroeconomic adjustments as well. Macroeconomic solutions to multifarious phenomena such as climate change and world hunger, nevertheless, are challenging for many reasons. First, many economists argue whether a unilateral or multilateral approach is best when working to solve such difficult and complex problems. Some contend that it should be up to individual states and NGOs to agree to standards. Others argue that global organizations such as the World Trade Organization (WTO) and the International Monetary Fund (IMF) or a yet unformed global power should exact authority on developed and developing countries to address the negative externalities of their trade relations (Brown, 2009). Secondly, the majority of environmentally damaging externalities are being produced by only a handful of developed countries. This brings forth an argument for focusing environmental standards on those nations who are the most culpable. Lastly, economists are divided over whether or not the cost associated with sustainable production measures is likely to lead to a slowdown of global economic prosperity. If conventional wisdom holds true, then it will continue to be very difficult to convince nations to adopt measures that may result in a loss of wealth for their respective nations. 
Arguably, a paradigm shift in thinking is needed in regard to nationalistic interests that may be in conflict with or in opposition to international interests. This suggests a kind of global citizenry, and a global ethic concerning the welfare of all people and all nations (Brown, 2009). This then points to the need for international organizations that are actively involved in the protection of economically distressed countries, impoverished peoples and protection against the advances of threats such as GCC. Hawken (2010) speaks to this need in addition to his support for microeconomic solutions. He supports the creation of both a national and an international environmental congress. The ex Prime Minister of the United Kingdom, James Gordon Brown, made a similar case calling on the need to rebuild our international institutions in order to meet the needs of the world today, given our knowledge of the threats of GCC and other threats such as the acceleration of worldwide poverty (Brown, 2009).

Brown suggests that international institutions such as the WTO and the IMF can be modified and strengthened and provided with the responsibility to protect world populations from known threats regardless of the country and irrespective of the condition of the population before the threat is realized (Brown, 2009). The WTO and the IMF can be recreated as necessary with clear objectives and responsibilities for the welfare of peoples around the planet. Armed with these adjustments, the WTO can enact regulations, trade agreements, sanctions, enforcement measures and physical support to those in need, particularly in developing countries lacking resources of their own. The IMF, supported by nations around the world can in turn sustain the WTO with the financial means necessary to meet these actions and objectives.

Although there are deep nuances involved in the current effort to use economic vehicles to help the environment, there are numerous possibilities available to use global economic policy to help the environment. For the sake of general simplicity, this following section will focus primarily on the WTO and its role in monitoring and mediating the global trade nexus. Although there are multiple global agencies in existence who specialize in the connectivity of nations, their financial power, and their position on the global stage, there is no other agency in existence with the authority to enforce trade barriers, raise tariffs, assign taxes or fees, or force specific economies to perform in a specific way.

\section{The World Trade Organization}

The World Trade Organization is a global group with exactly 164 members as of July, 2016 (WTO, 2016). Created in 1995 the WTO was created from the General Agreement on Tariffs and Trade (GATT). GATT, which was formed in 1947 after WWII (WTO, 2016). Similar to the International Monetary Fund (IMF), the GATT was created with the idea of establishing a general agreement on trade relations within an increasingly global economic system (WTO, 2016). The mission of the W'TO is to promote global trade among nations with the understanding that economic wealth can come from specialization and cooperation among producers of goods and services. The WTO services this idea by bringing in trade nations and facilitating their interactions in accordance to GATT jurisprudence (WTO, 2016).

Approximately $97 \%$ of the world's countries are members of the WTO. The sheer number of countries combined with the countless trade activities between all of them naturally leads to conflicts, seemingly growing with time and the complexities of trade agreements. As such, trade disputes are inevitable, and these disputes are meant to be resolved within the WTO system. Since all members of the WTO rely on each other in an interconnectivity of trade relationships, this harmony is what makes up the fabric of the trade relationships. The threat of retaliation against one member by another (or several) is meant to act as a restraint, in order to keep all members relatively honest with each other with regards to liberal trade policy (Brown and McCulloch, 2003, p 41).

When disputes arise, they are handled by committee and are usually mediated, often resulting in a specific regulatory policy between the two countries in question. Famous WTO disputes have involved the unsustainable harvesting practices of tuna fish and its negative impact on dolphin populations (Brown and McCulloch, 2003). As well as controversies on the presence of artificial hormones in US beef exports and the subsequent ban on US hormone beef in the European Union (Brown and McCulloch, 2003). The US, EU beef conflict is important because it sets a tone for societal standards of health and the impact of those standards on global trade. In this case, because the EU has determined that hormone content in beef is a public health hazard they have chosen not to import it from the US. Connections can easily be made between the hormone risk to human health and environmental pollution in the form of air and water quality, and GHG emissions. Yet, there is no voice of authority outside of sovereign countries altering their environmental standards, and consequently, there is little risk to producing products with negative environmental externalities other than a trade retaliation measure from a partner country (Brown and McCulloch, 2003).

Although the WTO has agreed that there is an obvious link between negative environmental externalities and global economic growth, the WTO has not proposed solutions that involve hindering world trade, after all, hindering trade is against what the WTO stands for. However, within the GATT principles is an article provision policy that states that world commerce should not be placed above our global responsibility to act as stewards 
toward the natural world (Brown and McCulloch, 2003). Article XX of GATT has been the strongest case that environmental economists have had to push the WTO into a stewardship role of environmental protection (Brown and McCulloch, 2003).

[N]othing in this Agreement shall be construed to prevent the adoption or enforcement by any contracting party of measures...necessary to protect human, animal or plant life or health...[or]...relating to the conservation of exhaustible natural resources (p. 1).

Article XX draws attention to the importance of natural capital, how it can be protected and the need to allow that protection as part of a global economic agenda. Just as our global society has decided that the buying and selling of immoral items like human slaves, endangered species, or weapons of mass destruction are not to be tolerated, the GATT has placed a general mandate that commerce needs to have a level of environmental protection associated with it. This leaves the WTO in a bit of a catch 22 situation. The mission of the WTO is to expand and promote trade liberation with the objective of global wealth. However, if the industrial activities of societies have reached a point where the marginal cost of economic growth is surpassed by the cost of climate change, and other detrimental consequences, then it would appear that the mission of the WTO should be altered to now curtail certain economic activity. Therefore, the cost of continuing to attempt to grow our economies following the strategy of the past, may be driving these economies to an operating loss simply because the total cost of producing goods and services will be more than the financial return, thereby defeating the mission of the WTO. Brown and McCulloch (2003) pose the question: "Could the trade expansion cause enough environmental damage to offset completely the resulting gains in national income?" (p. 9). Clearly, the costs of rising sea levels, more powerful storm systems, and worldwide drought point to the possibility that our capacity for global economic prosperity has been reached under our current trade policies?

Addressing these policies, however, and altering them to account for the costs of externalities such as those resulting from GCC, will also need to be done with the aid of international organizations. There is little debate that international problems require the assistance of international organizations and that these organizations can be quite successful at addressing problematic global issues. After all, GATT, the IMF and the EU were created in the wake of devastating world wars and economic depressions (Germany in the 1920s, the US in the 1930s), and have by most accounts responded well to the needs presented by these wars. Perhaps then, certain laws, provisions and mandates within these organizations can be used today to address global problems such as GCC? One suggestion has been to use article XX of the GATT to help pave the way for a global organization with sufficient power and authority to guide the world into environmental sustainability?

\section{A WORLD ENVIRONMENTAL ORGANIZATION AND THE MILLENNIUM DEVELOPMENT GOALS}

As Hawken (2010) puts it, there is this size thing that requires the need for global actions against global problems and this again points to the use of international organizations. If the aggregate of current global trade is creating a marginal cost that is greater than the marginal economic return and our natural capital is being depleted at unsustainable rates, then it is reasonable to suggest our societies are experiencing a hidden economic emergency, perhaps not seen since the days of the previous world wars. What is arguably more concerning though, are the hidden dangers that are a part of these looming economic and environmental cliffs. Just a few of these hidden dangers are the physical and financial risks of the consequences of GCC. Others such as over-fishing leading to seafood shortages and continued soil erosion leading to crop failures as well as desertification are just as disconcerting.

And yet our societies struggle mightily with a seeming lack of will to address these hidden dangers (Diamond, 2005). Meteorologists confirm that the side effects of climate change are slow, intangible and therefore are more abstract with regard to the time that it takes to feel it's effects, further complicated by the considerable lag time associated with the point of time of emission release and the time it takes to feel those effects (measured in decades). Partially as a result of this intangibility and lag time, the international actions of nations and the domestic policies within nations meant to dampen the causes of GCC have ranged from non-existent to ineffective. In addition, the countering forces against actions to curb GCC have included, but are not limited to mainstream Wall Street institutions. Unfortunately, many Wall Street institutions bolstered by the support of neoliberal and globalization advocates, still maintain that sustainable business practices are simply too expensive. Notwithstanding the increasingly evident reality that the threats to the current economic climate may be more severe than they were a century ago when national sovereignty was in the forefront of foreign policy. The argument here is that the world is operating at a loss, both economically and ecologically when the externality costs are included into the costs of goods and services. 
Positive changes to the WTO against the causes of GCC and other threats, however, hold the promise of making dramatic improvements to international efforts, and in doing so, providing positive impact, both nationally and worldwide. Recently, Hawken provided over 80 well-researched solutions to GCC that are best addressed by international efforts and that can best be accomplished with the aid of an international organization such as the WTO (Hawken and Steyer, 2017). As examples, providing much needed education to girls in developing nations and providing family planning in those same nations. When looking at the WTO as a still relatively young organization, established in 1995, it does appear to be within the realm of possibility that their mission can be redirected. Therefore, the WTOs mission can be adjusted to include a more direct objective of global industrial environmental sustainability awareness, and enforcement. Brown and McCulloch suggest as much through the establishment of a branch organization to the WTO calling it either a "Global Environmental Organization" (GEO) or a "World Environmental Organization" (WEO) (Brown and McCulloch, 2003, p. 19). For this paper, the term World Environmental Organization (WEO) has been chosen as this branch organization of the WTO (Brown and McCulloch, 2003).

Such an organization would be capable of formulating and enforcing appropriate policies that internalize all environmental externalities, i.e., capable of ensuring that all economic decisions in every country reflect global social costs and benefits (p. 19).

Although such an organization does not currently exist, and furthermore may now be considered an economic threat with regard to their potential unilateral authority to WTO members, this potential arm within the WTO may be a viable option in order to hold WTO members accountable to internalize costs associated with negative environmental externalities. Such a hypothetical organization as a WEO may be reasonably suited to account for and administer trade tariffs on par with the financial value of the environmental externalities associated with the production process in their total cost analysis. In addition, such a unilateral body could also administer trade sanctions to their trade policy similar to sovereign sanctions imposed on nations who engage in human rights violations and global terrorist sponsorship. As an example, an organization such as a WEO could place a tariff on weapons of all kinds and on the weapon makers - in line with the view of Hawken (2010) - supporting peacekeeping efforts and providing funds for reparations for those impacted by wars.

The work of the WEO will result in the growth of some economies and the suppression or the control of others such as those that rely too heavily on the use of fossil fuels. Therefore, there will likely be a concern that with some economies growing that favoritism is being granted or that growth will always result in greater harm to the environment either locally or globally. The favoritism arguments will need to be adjudicated through yet to be established WEO processes. The connection between economic growth and environmental damage, however, is well demonstrated by economic growth activities around the world. What may give this theory of a unilateral environmental and economic authority within the WTO strength though may be evidence gathered by Grossman and Krueger giving credence to the idea that economic growth is not contingent upon environmentally unsustainable business practices (Brown and MCCulloch, 2003).

Using cross-country data, they estimate the reduced-form relationship between GDP and various measures of national pollutants, such as urban air pollution, oxygen levels in river basins, fecal contamination of river basins, and heavy metal contamination of river basins. Decomposing the overall impact of national income into the scale, technique, and composition effects, they conclude that while higher GDP is related to higher pollution in the very poorest countries, beyond a certain GDP threshold (around $\$ 8000$ in 1985 U.S. dollars), further increases in GDP are typically associated with an improvement in environmental quality. This is the U-shaped relationship between national income and pollution subsequently labeled the environmental Kuznets curve (EKC) (p. 30).

The EKC is shown to be an empirical phenomenon in some cases, although the cause of lower emissions in these cases may be due to certain innovations and not a phenomenon that is general and therefore universally applicable (Stern, 2003). Even so, there is cause for optimism that some economies can grow and that with the addition of appropriate innovative technologies, then pollution from this growth can at least be abated.

The establishment of this WEO arm within the WTO is at this point, just an idea, however, it is one option to further address the need for international control of international problems. Some countries are going to oppose such an idea and others may be in favor of it. As Gordon Brown suggests though, key international institutions need to be reinvented in order to meet the needs of today and today these needs require this kind of global vision accompanied by a global ethic. Even so, there are bound to be those countries that will refuse to participate and who will insist that their economies be allowed to flourish without any restrictions of any kind.

One primary problem, as an example, is a scenario known as the prisoner dilemma based on Game Theory, which demonstrates why rational actors refuse to participate even when it suits their interest to do so. Thus, acting 
under the principles of the game theory, some actors incentivizing may elect to remove themselves from the WTO and open their own trade policies amongst themselves. This new anti-WTO trade relationship would no doubt operate at lower costs of production than WTO trade partnerships and could produce more wealth amongst themselves as a result (Brown and McCulloch, 2003). These kinds of revolts, although expected, will by necessity require certain enforcement measures and controls on the part of either the WEO acting independently or by the WTO. Countries that do decide to go it alone and defy WTO and WEO trade policies may be penalized by these organizations who may in turn enlist the assistance of the UN as needed to keep rogue nations from detrimentally impacting the world commons.

Arguably, an international organization such as the WTO is in the best position to address international disputes and to enforce international agreements for the benefit of jeopardized populations and their associated environments. With adjustments to the WTO or other branch organizations such as a WEO, broad and sweeping changes are also possible, the kinds of changes that are best addressed at the international level, such as limiting deforestation activities, curtailing coal consumption or protecting international waters from over fishing activities. As another example, a WEO could enforce eco-taxes for the use of virgin or old growth timber and by doing so, protect ecological systems by making their resources more costly than timber farm lumber. Changes at the state and national level to internalize certain externalities, however, also hold great promise to curtail harmful human activities and to have impact on the international level as well.

These kinds of microeconomic solutions are needed to compliment the macroeconomic solutions discussed above. Perhaps one of the strongest advocates for microeconomic solutions is Hawken (2010). As he suggests, consumption pattern alterations due to consumer awareness and the higher cost of goods and services with internalized externality costs hold the promise of altering local buying patterns, and by doing so altering harmful production practices around the world as well. Those who advocate for the internalizing of goods and services externality costs tend to believe that the consumer is the key to protecting our environments and to protecting vulnerable populations. The contention in this paper is that both these kinds of microeconomic solutions and the macroeconomic solutions discussed above are of critical importance to adequately address many of the most pressing issues facing the world today.

\section{MICROECONOMIC SOLUTIONS}

\section{Capital Management Raised Through Green Fees and Taxes}

The methods proposed to curb the production of harmful gases such as GHGs has been divided into two primary camps, those who wish to trade emissions and those who wish to tax emissions. Those opposing the trading of emissions or permits to emit pollution argue that this is nothing more than a money-making scheme for Wall Street traders and that this trading does not incentivize reduced pollution. As Hawken (2010) puts it, the problem with pollution permits is that they do just that - they permit pollution. The concern is that this is really just a smoke screen to the business as usual practice of foisting externalities onto others. The alternative of taxing pollution is delved into more deeply here, in agreement with Hawken's (2010) view that a simpler system of taxation is superior and less likely to be circumvented. Critically, however, green fees such as carbon taxes, and unlike pollution permits, provide revenue that can be used for purposes such as spurring innovation and investing in critical infrastructure.

By applying green fees and taxes to better represent the cost of a product, it stands to reason that low-income demographics will be negatively affected by such a change. This however, does not have to be the case. Hawken (2010) recognizes this conflict comparing existing US tax system as a means for leveling costs from one area to another. He emphasizes that the purpose of green taxes is not to raise revenue for the government (Hawken, 2010). Rather, "every incremental dollar collected from green fees should reduce income or payroll taxes, starting with the lower income brackets and moving toward the higher" (Hawken, 2010, p. 145). Further: "There are no positive incentives to be gained from taxing income or payroll, but there are also perverse incentives, the main one being cheating" (Hawken, 2010, p. 145). Cheating, is manipulating one's personal cash flow to pay as little as possible in taxes. Examples are offshore tax havens, and creative accounting practices in major business firms. "Green taxes would create, perhaps for the first time since the industrial age began, the closest thing to a free market, with many costs that are externalized now, fully accounted for" (Hawken, 2010, p. 145). The avoidance of paying taxes may be partly attributable to the structure of our current tax system wherein taxes are paid on positive societal factors; like income and company payroll (Hawken, 2010).

The key to redesigning the economy is to shift most taxes derived from "goods" to "bads," from income and payroll taxes to taxes on pollution, environmental degradation, and nonrenewable energy consumption. Because green taxes are incorporated into the price a company or customer pays for a 
resource, product, or service, they create powerful incentives to revise and constantly improve methods of production, distribution, and consumption, as well as a means to reconsider our wants and needs. The purpose of a green tax is to give people and companies positive incentives to avoid paying them ( $\mathrm{p}$. 146).

In addition to the advantage of benefiting from incentivizing consumers to reduce their taxes; Hawken (2010) suggests that it is also imperative that the revenue generated for the government is spent with the best interest of the commons in mind. For example, reducing budgets spent on military, or agrarian subsidies and in return spending tax revenue on projects with positive externalities, such as on resource protection, education, and renewable energy sources.

A worldwide or even a national shift in the assessment of taxes, recognizing the true and total cost of goods and services will be both a slow and monumental task. Given the problems with pollution resulting from consumption patterns, however, there is arguably no better way to curtail harmful consumption practices other than by at least partially internalizing the costs of externalities. Many alternative economists as well as mainstream economists are in agreement with the need to internalize externalities, at lease partially, into the cost of goods and services. In agreement with Hawken (2010), other alternative economists such as circular economists, green, and compassionate economists agree that this is a necessary step to curb the detrimental consequences of consumption such as GCC (Beeks, 2016). In addition to alternative economists, perhaps the strongest mainstream economist advocate for the inclusion of externality costs such as with a carbon tax is Paul Krugman (2010).

The challenges of incorporating green taxes into the cost of goods and services may be more challenging for developing nations. This need, however, can be met with the assistance of international organizations such as the WTO. Importantly, however, green fees can be estimated allowing us to be approximately right rather than completely wrong (Hawken, 2010). The taxes paid on cigarettes and on gasoline are green fees and are taxes on externalities, however, the amount of these taxes is not indicative at all of the cost of the externalities generated by the use of these products. Organizations such as the WTO, however, can apply green fees to products and they do not need to be exact, and yet will still act to encourage the production of certain goods and discourage the production of other goods with negative externalities. In addition, WTO developing nations will need assistance to help raise the capital needed to increase environmental measures within their borders (Brown and McCulloch, 2003).

In the global community, where differences between rich and poor are so much larger, there is no overall redistribution mechanism comparable to that applied within most individual countries, whether rich or poor. The international distribution of costs associated with protecting global commons therefore becomes an important consideration in policy design. In the highly improbable event that all can agree on the monetary equivalent of social costs and benefits, poorer countries with pressing immediate problems are likely to apply much higher discount rates to future benefits (p. 49).

This assistance in improving environmental standards in the developing world may come from several possible resources, such as the World Bank, with debt-for-nature swaps (Brown and McCulloch, 2003), and with the guidance of millennium development goals created by the EU. Important aspects of this shift in economic theory would need to be a fair system without shocks or sudden impacts to our economies. Similar to the public commons being regulated by each user, nation's tax services would need to work alongside the WTO in an effort to slowly restructure their own tax services to internalize the total cost of goods being sold around the world.

\section{CONCLUSION}

As a result of GHG emissions and the consequences of GCC, it is now well recognized that the need is here to reverse our negative trends both on the national and international levels. It is understood that it is in our interest to provide for one another and to ensure the survival of our species. Therefore, the case is made now that it is essential to make the kinds of changes proposed here, rebuilding our global society, establishing global citizenry and putting in place the systems needed to promote a global ethic for both people and the environment.

The Industrial Revolution, perhaps more than any event in human history, brought about technological advancements that allowed us to transform our world into one that resulted in widespread wealth and material accumulation and one that also allowed humans to exploit natural resources on a vast scale. Growth linked to resource consumption, however, comes with limits due to the capacity to which resources can be used. At the time and for many years after the Industrial Age, though, human societies behaved as though natural resources were limitless. Nonetheless, faced with the consequences of our consumption and pollution activities, particularly over the last 100 years or so, it is now quite clear that resources have limits and that human activities come with 
consequences. Our consumption and pollution activities have altered our planet and have placed us in what is now recognized as the Anthropocene Epoch, a new geologic age in which human activities have dominated all of the Earth's natural activities. This new epoch, evident by widespread species extinctions and global problems uniquely attributable to human activities, has provided us with an all too clear crossroad, a point in time in which our activities must be altered from the patterns of the past in order to meet the needs of the future (Klugler, 2014).

This new landscape is by necessity going to be one in which fossil fuel use is abandoned, and most if not all human activities will need to be carefully planned ahead of time, with limits and other restrictions placed on our actions for the sake of ecological systems and future generations. The results of GCC are now, in fact, highly tangible and more obvious, coming in the form of global food and water shortages and refugee movements away from climate danger areas (Davenport, 2014). Therefore, societies are faced with an economic and industrial system that demands more sustainable solutions. To this end, the internalizing of economic externalities and incentivizing economic growth in areas that promote positive societal and environmental results is considered by researchers such as Paul Hawken to be a strong solution and necessary for the long term success of a global society.

Incorporating green fees and green taxes places emphasis on areas of industry that are destructive to society incentivizing industry to reduce or eliminate that burden through sustainable innovation ( $\mathrm{Li}$, Lin and Muehlegger, 2014). Further, sustainably sound and environmentally efficient systems have been proven to be more cost effective in the aggregate and over a longer period of time. And even though far-reaching macro solutions are not simple, and would require global agreements and measures of accountability, these solutions are necessary given the new reality of a global society, with each nation now dependent on the actions of other nations. One of the biggest barriers to this new paradigm is that it opposes much of the neoclassical status quo of contemporary commerce. Even so, one of the greatest benefits possible with active and effective international organizations though, is a true free market system in which Adam Smith's invisible hand extends its reach in a way that negative externalities are accounted for and thus eliminated through the market's effort of correcting inefficiencies of production and trade.

History, buoyed by the works of researchers such as Jared Diamond have also shown us that societies are prone to failures as a result of shortsighted thinking and self-serving attitudes (Diamond, 2005). Diamond (2005) with his work Collapse: How Societies Choose to Fail or Succeed argues that many past societies drove themselves to collapse due to over consumption, a lack of far sightedness and the selection of poor leadership. Nevertheless, our species is also known for our overwhelming resilience and our ability to overcome tall barriers in an effort to seek better options for society. After all, slavery institutions have faded into the past, the cold war is over and colonial dominance over other cultures has been largely abated. Therefore, our potential for achieving great changes is apparent, not only as a matter of course, but as a consequence of learning from our mistakes. Now that humans are part of a truly globalized society, our kind simply must have the kinds of macroeconomic and microeconomic solutions presented here in order to alter our systems of global commerce to promote social justice, and to preserve our global commons.

\section{REFERENCES}

Anderson, R. (2007). Executive on a mission: Saving the planet. New York Times. Available at: http://www.nytimes.com/2007/05/22/science/earth/22ander.html?_r=0 (Accessed 22 May 2007)

Beeks, J. C. (2016). Which of the current diverse ideas on alternative economics are the best for adequately and comprehensively addressing the great transition to climate, energy, and biodiversity sustainability? (Doctoral dissertation, California Institute of Integral Studies San Francisco, CA). Available at: https://search.proquest.com/openview/aedc7d6b22498c95c2199f79c446f56c/1?pq-

origsite $=$ gscholar\&cbl $=18750 \&$ diss $=y$

Bentz, V. M. and Shapiro, J. J. (1998). Mindful inquiry in social research. Thousand Oaks, CA: Sage Publications, Inc.

Brown, G. (2009). Gordon Brown: Global ethic versus national interest. [Video]. Available at: http://www.ted.com/talks/gordon_brown_on_global_ethic_vs_national_interest?language=en

Brown, P. C. and McCulloch, R. (2003). Environmental issues in the World Trade Organization. (February, 2003). Department of Economics and Graduate School of International Economics and Finance, Brandeis University.

Citizen, D. (2014). The global green economy index. Washington, DC: Dual Citizen. Available at: http://dualcitizeninc.com/GGEI-Report2014.pdf

Davenport, C. (May 13, 2014). Climate change deemed growth security threat by military researchers. Available at: http://www.nytimes.com/2014/05/14/us/politics/climate-change-deemed-growing-security-threat-bymilitary-researchers.html?_r $=0$

Diamond, J. (2005). Collapse: How societies choose to fail or succeed. New York, NY: Penguin Group.

Hardin, G. (2009). The Tragedy of the Commons. Journal of Natural Resources Policy Research, 1(3), 243-253. https://doi.org/10.1080/19390450903037302 
Hawken, P. (2010). The ecology of commerce: A declaration of sustainability (3rd ed.). New York, NY: Harper Collins Business.

Hawken, P. and Steyer, T. (2017). Drawdown: The Most Comprehensive Plan Ever Proposed to Reverse Global Warming. New York: Penguin Books.

Hill, A. and Clifford, J. (2016). Market failures, taxes, and subsidies: Crash course economics \#21 [Video]. Available at: https://www.youtube.com/watch?v=13JOGWzY8kE (28 May 2016)

Klein, N. (2014). This changes everything: Capitalism versus the climate. New York, NY: Simon and Schuster.

Klugler, J. (2014). The sixth great extinction is underway - and we're to blame. Time science. Available at: http://time.com/3035872/sixth-great-extinction/ (Accessed 25 July 2014)

Krugman, P. (2010). Building a green economy. The New York Times Magazine, 5, 2-16.

Li, S., Linn, J. and Muehlegger, E. (2014). Gasoline taxes and consumer behavior. American Economic Journal: Economic Policy, 6(4), 302-342. https://doi.org/10.1257/pol.6.4.302

Mabee, W. E., Mannion, J., and Carpenter, T. (2012). Comparing the feed-in tariff incentives for renewable electricity in Ontario and Germany. Energy Policy, 40, 480-489. https://doi.org/10.1016/j.enpol.2011.10.052

McKibben, B. (2011). eaarth: Making a life on a tough new planet. New York, NY: St. Martin's Press.

Montuori, A. (2008). Foreword: Transdisciplinarity, in B. Nicolescu (Ed.), Transdisciplinarity: Theory and practice (pp. ix-xvii). Cresskill, NJ: Hampton Press. https://doi.org/10.1002/qua.21708

Montuori, A. (2010). Research and the research degree: Transdisciplinarity and creative inquiry, in M. Maldonato \& R. Pietrobon (Eds.), Research on scientific research: A transdisciplinary study (pp. 110-135). Portland, OR: Sussex Academic Press.

Panwar, N. L., Kaushik, S. C. and Kothari, S. (2011). Role of renewable energy sources in environmental protection: a review. Renewable and Sustainable Energy Reviews, 15(3), 1513-1524. https://doi.org/10.1016/j.rser.2010.11.037

Pigou, A. C. (2013). The Economics of Welfare. New York, NY: Palgrave Macmillan.

Stern, D. I. (2003). The environmental Kuznets curve. Rensselaer Polytechnic Institute, Department of Economics, Troy, NY 12180. Available at: http://isecoeco.org/pdf/stern.pdf

The Economic Times. (2017). India, China investing more in renewable technologies: John Kerry. The Economic Times. Available at: http://economictimes.indiatimes.com/industry/energy/power/india-china-investingmore-in-renewable-technologies-john-kerry/articleshow/51709915.cms?intenttarget $=$ no

The Guardian. (2017). Just 100 companies responsible for $71 \%$ of global emissions, study says. The Guardian. Available at: https://www.theguardian.com/sustainable-business/2017/jul/10/100-fossil-fuel-companiesinvestors-responsible-71-global-emissions-cdp-study-climate-change?CMP =ema-1706\&CMP=

The World Trade Organization (WTO). (2016). The World Trade Organization: Members and observers. Available at: https://www.wto.org/english/thewto_e/whatis_e/tif_e/org6_e.htm

Wells, J. (2013). Complexity and sustainability. New York, NY: Routledge. 